\title{
Szentnémedy (Willwerth) Ferenc vezérkari ezredes élete és katonai pályafutása n.rosz
}

$\mathrm{S}$ zentnémedy 1896. november 12-én, Willwerth Ferenc Alajos néven, szegény iparos szülők gyermekeként született a Krassó-Szörény vármegyei Orsován (ma: Románia) erdélyi szász származású családba. Édesanyját, Palithy Júlia Rózát (1876-1907) és édesapját, Willwerth Ferencet (1869-1911) meglehetősen korán elveszítette. Iskolái közül a 4 elemi osztályt (1902-1906) és 4 polgári iskolai osztályt (1906-1910) még Orsován végezte, majd a temesvári császári és királyi hadapródiskolában folytatta tanulmányait. Ez utóbbi elvégzését követően (1914. augusztus 1-jén) zászlóssá avatták, és a cs. és kir. 5. gyalogezredbe nyert beosztást, amelynek kötelékében augusztus 21 -én került ki a frontra. ${ }^{1}$

Az ezred a miskolci 15. gyaloghadosztállyal vonult a keleti harctérre, amely a 4 . hadsereg, ezen belül is a VI. had-

1. ábra. Willwerth Ferenc egyetlen ismert gyermekkori fényképe

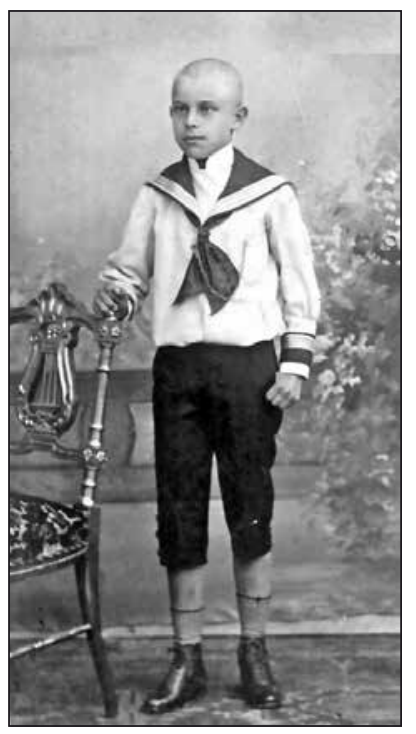
test alárendeltségébe tartozott. Willwerth 1917. május 1-ig küzdött az 5. gyalogezred kötelékében szakasz-, majd századparancsnokként, ezt követően pedig zászlóalj és ezred segédtisztként szolgált. Egysége 1914-ben részt vett a komarowi, a lembergrawaruskai csatákban, valamint a San folyó menti harcokban és a krakkói ütközetben - ez utóbbiaknál már inkább a XIV., és helyenként a XVII. hadtesttel - komoly veszteségeket szenvedve. A decemberi offenzíva során még előrehatoltak egészen a Dunajec partjáig, 1917 januárjában azonban az 5. gyalogezredet átirányították Bukovinába, a 7. hadsereghez. Jelen írás keretei nem teszik le-

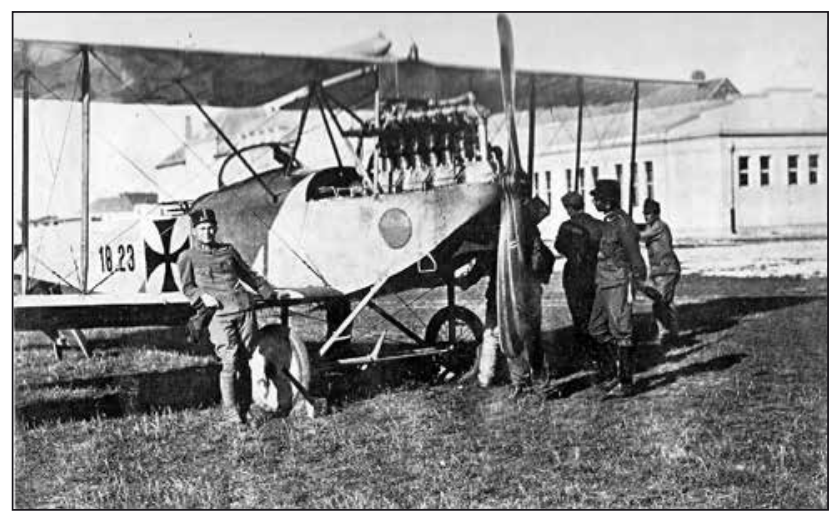

2. ábra. Willwerth a $\mathbf{1 8 . 2 3}$ számú Lohner C.I-es iskolagépnek támaszkodva, a wiener neustadti repülötéren

hetővé a gyalogsági harcok részletes bemutatását, ${ }^{2}$ azt azonban fontos kiemelni, hogy Willwerth e küzdelmek során többször is felhívta magára felettesei figyelmét, számos elismerésben részesítették. Már a harcok korai szakaszában kitüntette magát. Még zászlósként, 1914. december 2-án az ellenfél előtt tanúsított vitéz magatartásáért a 1. osztályú Ezüst Vitézségi Érmet adományozták számára. 1915. január 1-jén kinevezték hadnaggyá, majd február 11-én a Bronz Katonai Érdemérem a kardokkal elismeréssel tüntették ki. A bukovinai harcok során sem hagyott alább ténykedése, ezt az Ezüst Katonai Érdemérem a kardokkal kitüntetés kétszeri (1915. július 17. és 1916. augusztus 6.) adományozásával honorálták, 1916. november 1-jén pedig főhadnaggyá léptették elő. ${ }^{3}$

Időközben az Osztrák-Magyar Monarchia repülőcsapatainak (k.u.k. Luftfahrtruppen) mind nagyobb szüksége mutatkozott legénységi és tiszti személyzetre az egymás után felállított századokhoz, erre pedig leginkább a szárazföldi egységek soraiból számíthatott. Sok társához hasonlóan, Willwerth is jelentkezett a repülőkhöz. Jelentkezését elfogadták, majd megfigyelőtiszti kiképzésre küldték, amelyet 1917. május 15. és július 15. között végzett el Wiener
ÖSSZEFOGLALÁS: A Magyar Királyi Honvéd Légierő legmeghatározóbb katonai teoretikusa és szakírója Szentnémedy (Willwerth) Ferenc vezérkari ezredes volt. Szentnémedy két világháború közötti tevékenységét prof. Dr. M. Szabó Miklós altábornagy, hadtörténész, az MTA rendes tagja, a Zrínyi Miklós Nemzetvédelmi Egyetem volt rektora már elemezte és publikálta, ám a teoretikus pályafutásának I. világháborús szakaszát e cikk mutatja be elsőként.

KULCSSZAVAK: Szentnémedy (Willwerth) Ferenc, Osztrák-Magyar Monarchia, Magyar Királyi Honvéd Légierő, katonai teoretikus
ABSTRACT: The most prominent military theorist and professional writer of the Royal Hungarian Air Force was Staff Colonel Ferenc Szentnémedy (Willwerth). Szentnémedy's two world wars activities prof. Lieutenant General Dr. Miklós M. Szabó, military historian, ordinary member of the Hungarian Academy of Sciences, former rector of the Zrínyi Miklós National Defence University, has already analyzed and published Szentnémedy's activities between the two World Wars, but this article presents the World War I period of the theorist's career for the first time.

KEY WORDS: Ferenc Szentnémedy (Willwerth), Austro-Hungarian Empire, Royal Hungarian Air Force, military theorist 


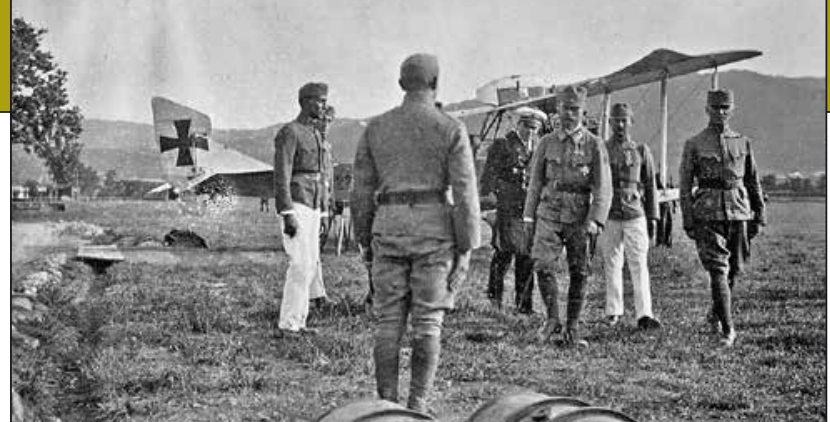

3. ábra. József Ferdinánd föherceg látogatása a Flik 32-nél 1917. augusztus elején

Neustadtban, a repülőtiszti iskolában (Fliegeroffizierschule). A képzést követően a Flik 32-eshez ${ }^{4}$ osztották be, ahová 1917. július 18-án érkezett meg. A Richard Hübner százados vezetése alatt álló repülőalakulat az Isonzó-hadsereg alárendeltségében tevékenykedett és a Wippach-völgyben (ma: Vipava folyó völgye, Szlovénia) fekvő St. Veit (ma: Podnanos, Szlovénia) repülőterén állomásozott két másik repülőszázaddal. Az egység általános felderítő feladatokat látott el, amihez a kiváló Hansa-Brandenburg C.I típusú repülőgépeket használták. Ebből június 30-án 6 bevethető példány állt rendelkezésükre, a következő hónapban pedig már 1 Hansa-Brandenburg D.I típusú vadászgép is csatlakozott a felderítőkhöz. ${ }^{5}$

Willwerth 4 bevetést repült megfigyelőként 1917. július második felében, az utolsót 31-én, amely egy komoly öszszecsapást és meghatározó élményeket hozott számára. Pilótája, Franz Fraueneder tizedes a 229.03 jelű HansaBrandenburg C.I-es kormányánál élte át az akció izgalmait, amelyeket az Arany Vitézségi Érem odaítélése okán készített részletes beszámolójából ismerhetünk meg: „1917. július 31-én megszereztem a másik kitüntetéseimhez az aranyat. Reggel 7-kor startolt a Flik 323 felderitö repülögépe a Wippach-völgyböl a front irányába. Nekem Willwerth föhadnaggyal, mint megfigyelővel kellett egy nehéz fotórepülést végrehajtanom Tolmein környékén. A felvételeket néhány kilométerrel az ellenséges vonalak mögött, alacsony magasságon és a fényképezett terület nagy kiterjedésében kellett megcsinálni.

A hegyes terepnél és jól belőtt elhárító ütegeknél a megbízatás sok nehézséget jelentett, amin ügyességgel és sok szerencsével kellett túlesni. A két másik repülögépnek, amelyek velünk szálltak fel, az volt a feladata, hogy megvédjenek bennünket az ellenséges repülők zaklatásától a fényképezés alatt, hogy mi a munkánkat végre tudtuk hajtani. Minden kívánság és parancs szerint ment. A felvételek elkészültét követően a két kísérőnk más irányt vett, hogy a saját feladataikat elvégezzék.

Az ellenséges repülö-elhárítás tüzében az Isonzó mentén repültünk a Monte San Gabriele irányába a saját reptérre, a Wippach-völgybe. A látótávolság 10-20 km-t tett ki és a földfelszín felé pedig az időközben felvett 2000-2300 méteres magasságból párás volt. Kis felhőcskékkel robbanó lövedékeket láttam magam előtt a levegőben, amelyek a saját légelhárító ágyúinktól származtak, ez ellenséges repülőgépek jelenlétére utalt a közelben. Szorgos keresgélés ellenére sem láttuk őket, mivel nem voltak a látóterünkben.

Egy rövid időtartamban, amit ilyen esetekben egyáltalán nem lehet pontosan megadni, mivel a feszültség és a veszély pillanataiban az időt nem figyeli az ember, hallottam mögöttem egy Nieuport (olasz vadászrepülögép) géppuskájának ropogását, közben a megfigyelömét is, akik szinte egyidejüleg lőttek.

Az ezt követő fordulómanőver során, hogy új lövési lehetőségekhez jussunk, észrevettem elöttem, a pilóta géppuskám lőterében egy második Nieuportot. Leadtam rá egy sorozatot, egyenesen a törzs közepébe és láttam utána oldalirányban eltünni (lezuhanni). Az első Nieuport, amelyik elöször lőtt ránk, most a második sorozatát közvetlenül a mi

$68 \Rightarrow$ HADITECHNIKA LIII. évf. 2019/1

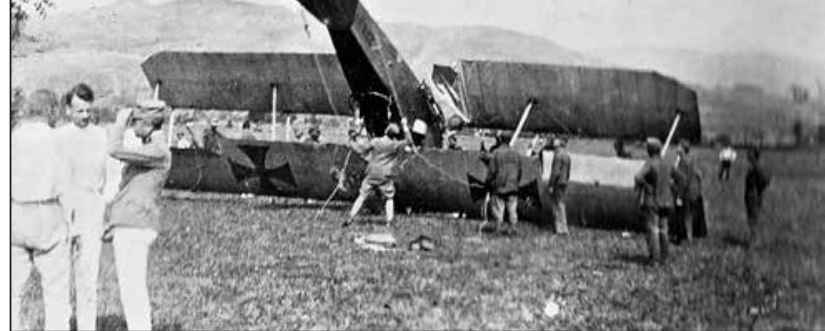

4. ábra. A 229.03 jelü Hansa-Brandenburg C.I-es landolást követően - talán épp Willwerthék 1917. július 31-i bevetése után

gépünk törzsének közepébe eresztette, és elrepült a törzsünk végénél, mintha nekünk akart volna jönni. 4-5 méterrel a szemem elött láttam a pilóta arcát. Közben hallottam a két géppuska ropogását és a túlpörgetett motorok robaját.

Az volt az érzésem, hogy rövidesen összeütközünk és már láttam magunkat roncsokként a mélybe zuhanni. A rettenet pillanata volt. Hirtelen eltünt az ellenfél és a gépem leadta a szárnyát.

Amikor újra egyenes repülésben a saját repterünk felé repültünk, ránéztem a megfigyelömre, mozdulatlanul feküdt a törzsben. A repülés alatt részben mégis magához tért és két lyukra mutatott a bőrkabátján, két életveszélyes lövés a hastájékon. Kényszerleszállást akartam csinálni a front mögött az elsősegélynyújtó helyen, de jelezte, hogy haza akar menni és így hazafelé repültem a hősies megfigyelömmel, pillantásokkal és gesztusokkal tartottam benne a lelket.

Leszállásnál a saját repülöterünkön a lövésektöl súlyosan eltalált futómü összetört. A segítőcsapatok odasiettek és a megfigyelöt rögtön a kórházba vitték.

A gép sok helyen át volt lyuggatva és az oldalkormány felső része az ellenséges repülővel történt érintőleges ütközésnél leszakadt. Ezzel megtörtént az a ritka eset a háborúban, hogy két gép légi harcban összeütközött. Később még jött a gyalogsági megfigyelők jelentése, akik figyelemmel kísérték a légi harcot, hogy mindkét ellenséges repülö az olasz vonalak mögött lezuhant.

Josef Ferdinánd föherceg, a föszemlélö és Uzelac ezredes, a k.u.k. Luftfahrtruppen parancsnoka gratuláltak nekem ehhez a sikerhez és így megkaptam az Arany Vitézségi Érmet."6

A gép pilótája egyébként bécsi származású volt, foglalkozását tekintve lakatos és a pilótaképzést követően 1916. október végén osztották be a századhoz. A tapasztaltnak számító repülő az összecsapást megelőzően már 51 bevetés részese volt, majd 1918 februárjában oktatóként áthelyezték a klagenfurti repülőpótszázadhoz. ${ }^{7}$ Neki köszönhető, hogy Willwerth has- és gyomorlövéstől súlyosan megsebesülve, visszatérhetett a saját repülőterükre. A légi harc Zagora felett, Görztől (ma: Gorizia, Olaszország és Nova Gorica, Szlovénia) kb. 9 km-re északra folyt, és az osztrákmagyar személyzet számára mindkét Nieuport lelövését igazolták. Willwerth az akcióban történt részvételéért a 3. osztályú Vaskorona Rendet kapta meg. ${ }^{8}$

\section{5. ábra. A feltrei repülőtér felülnézetből}

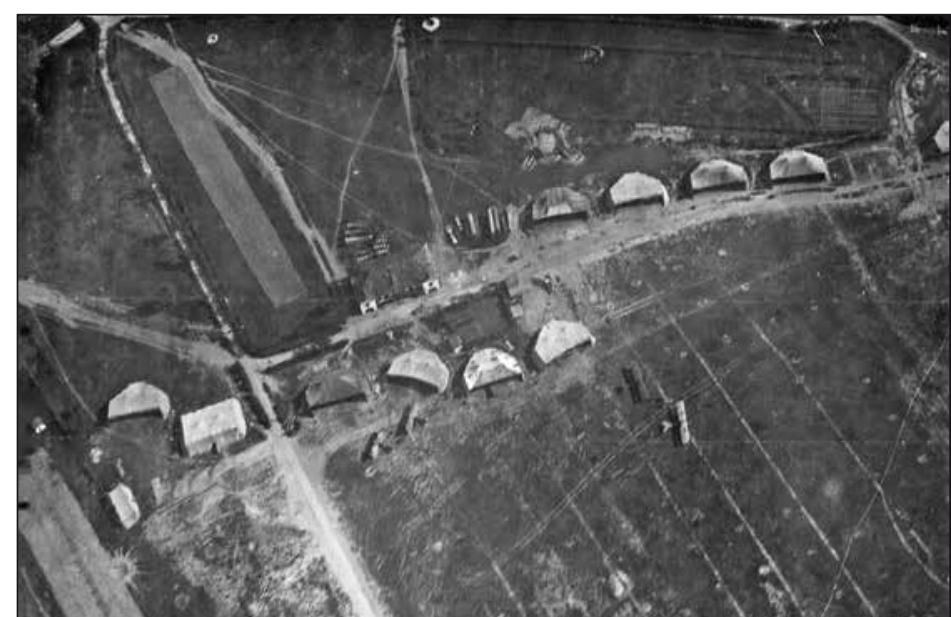


6. ábra. Motorpróba a Flik 39/D egyik Hansa-Brandeburg C.I-es felderítőgépén

Felépülése alatt ideiglenesen a repülö-pótalakulatok (k.u.k. Fliegerersatztruppen) állományába került, majd 1918. január 4-én érkezett meg új egységéhez, a Flik 39/Dhez. Ezt a repülőszázadot a 12. isonzói csatára készülve irányították át az olasz frontra, először az 1. Isonzó-hadsereg és a XVI. hadtest alárendeltségében Wippach repülőteréről tevékenykedtek, majd a frontvonalat követve decemberben a német 14 . hadsereg, ezen belül a cs. és kir. I. hadtest berkein belül, Avianón települtek. A január és február első fele lényegében további áttelepülésekkel telt, ezt követően érkeztek meg Feltre repülőterére, amely szeptember közepéig otthonul szolgált számukra (továbbra is az I. hadtest alatt, de immár a 11. hadseregnek alárendelve, a Grappa-fronton). A parancsnoki poszton hasonlóan sürü változások történtek, 1917. decembertől 1918. január végéig Rudolf Dworzak főhadnagy töltötte be átmenetileg, tőle Fritz Wödl főhadnagy vette át a vezetést és egészen októberig ő is maradt a század élén - kivéve a május-júniusi időszakot. Az alakulat a Hansa-Brandenburg C.I-esek mellett együléses Phönix D.I típusú vadászgépeket is repült, föleg a felderítők védelmében. ${ }^{9}$

Az állandósult költözések közepette nem csoda, ha a század hajózó személyzete februárig szinte egyáltalán nem járt bevetésekre. Willwerth-et beiskolázták még azelőtt, hogy bármit bizonyíthatott volna: február 12-26. között egy fotókurzuson vett részt. A végleges letelepülést követően, az időközben megváltozott erőviszonyok hatása a Flik 39/D számára is hamar megmutatkozott. A mindössze néhány repülésre alkalmas napon 2 pilótáját veszítette el az alakulat légi harc során: Alois Weinert szakaszvezető február 18-án, Josef Santler tizedes február 24-én maradt alul légi összecsapásban együléses vadászgépeikkel repülve. Március 10-én támadás érte Feltre repülőterét minden bizonnyal ezen események miatt - március első felében a Flik 39-es egyáltalán nem repült bevetést. Április 25-én egy újabb veszteséget volt kénytelen elszenvedni az alakulat, Roland Lehnert szakaszvezető gyakorlórepülés közben lezuhant és életét vesztette. Májusban ráadásul különösen felerősödött az olasz légi tevékenység a körzetben és több bombatámadás is érte a feltrei repteret. $A z$ olasz repülőgépek kétségkívül május 24-én reggel bizo-

\section{7. ábra. Willwerth Ferenc feltrei szállásán}

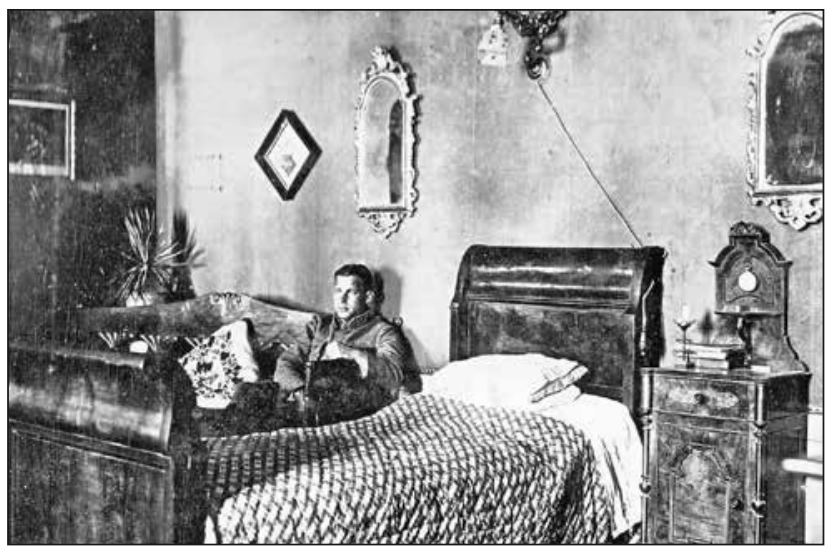

nyultak a legeredményesebbnek: a Flik 39/D egyik sátorhangárja teljesen kiégett, 2 további pedig megsérült, a gépek közül 1 felderítő lényegében megsemmisült, 4 további felderítő és 1 vadászgép megrongálódott.

A repülőgéphiány és a veszteségek tükrében kell nézni azokat az alacsony számokat, amelyek az egység bevetéseit mutatják: márciusban 7 (más adatok szerint 8), áprilisban 2, májusban 10, júniusban 12, júliusban pedig 9 alkalommal jártak ellenség felett a Flik 39/D repülői. Willwerth Ferenc áprilisban vett részt először - és a hónapban egyetlen alkalommal - akcióban, a következő 2 hónapban ismét 1-1 alkalommal került rá sor, hogy bevetésre induljon. A július 1. és augusztus 7. közötti időszakot szabadságon töltötte, majd visszatérte után, augusztusban 3 alkalommal járt a front felett. ${ }^{10}$ Érdemes megemlíteni, hogy 1918 júniusában az egység jelzése Flik 39/P-re változott, ami fotófelderítő századot jelentett (a korábbi általános jellegű, „D” betűvel jelzett ún. hadosztály-repülőszázadhoz képest), kizárólag együléses fotófelderítő vadászgépekkel vagy ezek keveréke kétüléses felderítőgépekkel.

Augusztus hónapja meglehetősen eseménydúsan telt Willwerthék alakulata számára. Az egyértelmű antant légi fölény következtében mind sürübben és egyre nagyobb számban jelentek meg az ellenséges repülőgépek a levegőben, szinte lehetetlenné téve a felderítő munkát. A gyakori találkozások értelemszerüen magukkal hozták az öszszecsapásokat is, az eredmény: 14 bevetés során 2 légi győzelem és 2 veszteség. Augusztus 5-én a századparancsnok harmadmagával, vadászgépekkel repülve keveredett légi harcba brit Sopwith Camelekkel, amelynek során Fritz Wödl főhadnagy igazolt győzelme mellett, Paul Schremser tizedes megsebesült. 15-én pedig a korábbi parancsnok, Rudolf Dworzak főhadnagy életét vesztette a brit vadászokkal történt küzdelemben, a pilóta, Konrad Seiboth tiszthelyettes sebesülten hozta le UFAG C.I-es felderítőgépüket. (Egy ellenséges gép lelövését igazolták számukra. ${ }^{11}$ )

Az utolsó piavei offenzívára készülve, a századot áthelyezték a 6. hadsereg, pontosabban a Grappa-frontot felügyelő Belluno hadseregcsoport alárendeltségébe. A Karl Jasny százados parancsoksága alatt, San Pietro in Campo repterén települt alakulat tevékenységéről azonban - ahogy ez már javarészt 1918 szeptembertől kezdődően jellemző - szinte semmilyen adat nem maradt fenn.

A világháború befejezését követően Willwerth az újonnan felállított, önálló magyar repülőcsapatokhoz jelentkezett és az Aradon, majd innen a román támadás következtében egészen Budapestig visszavonuló 6. repülőosztály - később 6. (vörös) repülőszázad - állományába nyert beosztást. Bár a saját adatain alapuló anyakönyve szerint a Tanácsköztársaság végéig ezen alakulatnál szolgált, a fennmaradt iratokban nem található jelentés arról, hogy akár egyetlen bevetést is teljesített volna. Ismert ugyanakkor, hogy egysége Abony-Sashalom repterén tartózkodása idején, pontosan 1919. április 27-én Willweth-et több társával együtt átirányították a Hadügyi Népbiztossághoz. ${ }^{12}$

8. ábra. Egy „Brandi” startja a feltrei reptérről

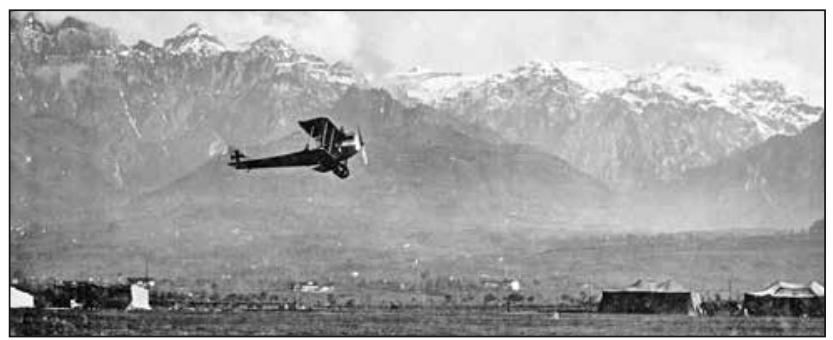


